\title{
A Study to Assess the Knowledge Regarding Bio- Medical Waste Management among B.Sc Nursing Students of Selected Nursing Colleges of Udaipur (Raj)
}

\author{
Vijayamma Ajmera ${ }^{1}$, Dr. Jayalkshmi L. S. ${ }^{2}$ \\ ${ }^{1}$ Ph.D Scholar, Principal, Govt. College of Nursing, Udaipur (Raj.), India \\ ${ }^{2}$ Dean, Geetanjali College of Nursing, Udaipur (Raj.), India
}

Running Title: Knowledge on Biomedical Waste Management among Nursing Students

\begin{abstract}
Medical care is vital for our life, health and well being. But the waste generated from medical activities can be hazardous, toxic and even lethal because of their high potential of disease transmission. Illegal and unethical reuse can be extremely dangerous and even fatal. The present study was undertaken to assess the knowledge regarding biomedical waste management among B.sc. nursing students at Udaipur, Rajasthan. 120 samples were selected using probability sampling. The findings revealed that high level of knowledge among respondents was $61.67 \%$, moderate level of knowledge among $33.33 \%$ and low level of knowledge was $5 \%$ among respondents regarding BMW management. The study concluded that low level of knowledge was found in the areas such as source of origin of biomedical management such as source of origin, disposal of waste, disease transmission, etc. Following the study, the investigator provided an information booklet which will help the bsc nursing students to enhance their knowledge. The study also revealed that there is no significant association between knowledge scores and demographic variables
\end{abstract}

Keywords: Biomedical waste, Knowledge, Practice

\section{Introduction}

Hospitals and other health care institutions are one of the essential commodities of daily life. They generate "wastes" day in and day out which may be the potential health hazards to health workers. While hospitals claim to dispose off their wastes as per the stipulated norms, it is shocking to note that much of the infectious waste including needles, syringes, catheters, etc. are being recycled only to find its way back into the market. Waste requiring special attention includes, those that are potentially infectious, sharps e.g. needle, scalpels, other subjects capable of puncturing the skin, plastic waste establishments, pharmaceutical waste and a variety of chemically hazardous waste used in laboratories.

Keeping in view inappropriate biomedical waste management, the Ministry of Environment and Forests notified the "Biomedical Waste (management and handling) Rules, 1998" in July 1998. In accordance with these Rules (Rule 4), it is the duty of every "occupier" i.e. a person who has the control over the institution and or its premises, to take all steps to ensure that waste generated is handled without any adverse effect to human health and environment and the waste is treated within 48 hours period.

\section{Need for Study}

Health care institutions are one of the essential commodities of daily life. They generate "wastes" day in and day out which may be the potential health hazards to health workers.
The adequate management of wastes assumes tremendous importance in a country like India, whose economy forces the poverty stricken and ignorant ragpickers to sift and soft through dumped waste materials in order to earn subsistence.

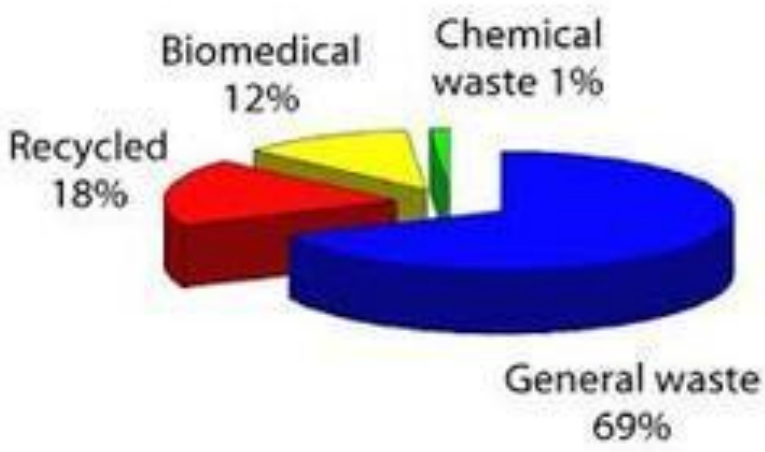

While hospitals claim to dispose off their wastes as per the stipulated norms, it is shocking to note that much of the infectious waste including needles, syringes, catheters, etc. are being recycled only to find its way back into the market. Although health care wastes comprise a very small portion of the entire waste stream, it deserves special attention because of the hazards it can pose to human health. Waste requiring special attention includes, those that are potentially infectious, sharps e.g. needle, scalpels, other subjects capable of puncturing the skin, plastic waste establishments, pharmaceutical waste and a variety of chemically hazardous waste used in laboratories Handling, segregation, mutilation, disinfection, storage, transportation and final disposal are vital steps for safe and scientific management of biomedical waste in any health set up for which the health care workers 


\section{International Journal of Science and Research (IJSR) \\ ISSN (Online): 2319-7064 \\ Index Copernicus Value (2013): 6.14 | Impact Factor (2015): 6.391}

are to be trained. Personnel responsible for the disposal of BMW were not adequately trained which lead to inappropriate management and insufficient implementation of regulations. Employees indiscriminately used coloured bags without any organised segregation or treatment. The present scenario of BMW management in Indian hospitals is grim and it should be mandatory for health care establishments to ensure that such waste is handled without any adverse effects to human health.

Handling, segregation, mutilation, disinfection, storage, transportation and final disposal are vital steps for safe and scientific management of biomedical waste in any health set up for which the health care workers are to be trained.

Studies conducted concluded that regular training and awareness about waste management activities among nursing personnel needs tobe held to increase knowledge regarding hospital waste management.

\section{Statement of problem}

A study to assess the knowledge regarding bio-medical waste management among B.Sc nursing students of selected nursing colleges of Udaipur (Raj) with a view to develop an information booklet.

\section{Objectives of the study}

1) To assess the knowledge regarding bio-medical waste management among B.Sc nursing students.

2) To find out the association between knowledge scores and selected demographic variables regarding biomedical waste management.

3) To prepare and distribute and information booklet on biomedical waste management among B.Sc nursing students.

\section{Methodology}

Research approach and design: To assess the knowledge regarding biomedical waste management among B.Sc. nursing students a descriptive design with cross sectional survey approach was used.

\section{Setting of the study}

The study was undertaken in Saraswati College of Nursing, Udaipur College of Nursing \& Sanjeevani College Of Nursing, Udaipur.

\section{Population:}

The population for the study comprised B.Sc. Nursing students of part 2,3 and $4^{\text {th }}$ of selected nursing colleges.

\section{Samples}

Samples of the study were B.Sc. Nursing students of the selected colleges of Udaipur.

\section{Sample size}

Sample size were 120.The samples included 40,35 and 45 students respectively from each college.

\section{Sampling technique}

In the present study the B.Sc. Nursing students were selected by simple random sampling (Lottery method).

\section{Inclusion criteria}

The following inclusion criteria are set to select the samples.

- B.Sc. Nursing students

- Students available at the time of data collection

- Studying in II, III and IV year.

- Those who have Consented to participate in the study.

\section{Exclusion criteria}

Samples excluded in the present study were students,

- Not available at the time of data collection.

- Those who were not consented to participate in study.

\section{Description of the Tool}

A structured knowledge questionnaire was prepared and used to assess knowledge regarding BMW Management based on the objectives containing 22 questions.

Section A: Consisted of items on demographic data age, Sex, class, area of residence, awareness and source of information.

Section B: Consisted of structured knowledge questionnaire on Biomedical waste management based on the following aspects.

- source of origin of biomedical waste

- waste management and handling rules

- disease transmission

- color coding

- segregation of waste

- disposal of waste

The tool used was tested for validity and reliability and a pilot study was conducted to establish the feasibility and administering the tool.

\section{Validity of the Tool}

Items were judged by experts for relevance, clarity and appropriateness. Modifications were done in the tool as per expert opinion.

\section{Reliability of the Tool :}

Reliability was established by split Half method.

The steps adopted for development of information booklet were as follows-

- Review of Literature

- Journals, Books, internet as sources used

- Opinions and suggestions from guide

The contents covered the following areas-

- Definition of Biomedical waste

- Sources of BMW

- Categories of BMW

- Colour coding system

- Treatment options of wastes

- Instruction to staff who handle clinical wastes.

- Nurses role and responsibilities in BMW management. 


\section{International Journal of Science and Research (IJSR) \\ ISSN (Online): 2319-7064 \\ Index Copernicus Value (2013): 6.14 | Impact Factor (2015): 6.391}

\section{Data Collection Procedure}

Written permission was obtained from Principals of Saraswati College of Nursing, Udaipur College of Nursing, Sanjeevani College of Nursing, Udaipur prior to data collection. The sample included 40, 35 and 45 students respectively from each college. The purpose of the study was explained to participants, and assured the confidentiality of their response. The information booklet was administered to the participants.

\section{Plan for data analysis}

Data were analyzed as follows:

- Described demographic chacteristics.

- Mean, SD, and mean \% were used to describe area wise knowledge scores.

- Annova and , $Z$ ' test used to find out association of knowledge with demographic variables.

\section{Results}

The demographic characteristics of the respondents revealed that-

Similar percentage of respondents $40.83 \%$ each belongs to the age group 20-21 and 21 and above, $12.50 \%$ of respondents to age group of $19-20$ and only $5.83 \%$ belongs to $18-19$ years of age.Majority $71.6 \%$ of respondents were male and $28.33 \%$ were female.
The findings shows that the percentage of male candidates (71.67) migrating in B.Sc nursing course is more than female(28.33) candidates.

Majority $53.33 \%$ of respondents belongs to III yr. B.Sc nursing, $30.83 \%$ in II yr. and $15.83 \%$ in IV yr. B.Sc nursing.

Majority $94.17 \%$ of respondents were aware about BMW management and only $5.83 \%$ of respondents were not aware of BMW management.

Majority $63.33 \%$ of respondents got information from teachers, $23.33 \%$ from health team members, $15 \%$ from mass media, $0.83 \%$ from friends.

Equal percentage, 50\% each of respondents belong to rural and urban background

\section{Area wise percentage of knowledge scores}

\begin{tabular}{|l|c|c|}
\hline \multicolumn{1}{|c|}{ Area of Knowledge } & Mean & SD \\
\hline Source of Origin & 57.50 & 49.64 \\
\hline Waste Management and Handling Rules & 84.17 & 21.97 \\
\hline Disease Transmission & 51.67 & 22.39 \\
\hline Color Coding & 91.11 & 19.68 \\
\hline Segregation of Waste & 63.33 & 28.79 \\
\hline Disposal of Waste & 45.83 & 18.07 \\
\hline Treatment of BMW & 54.58 & 34.90 \\
\hline
\end{tabular}

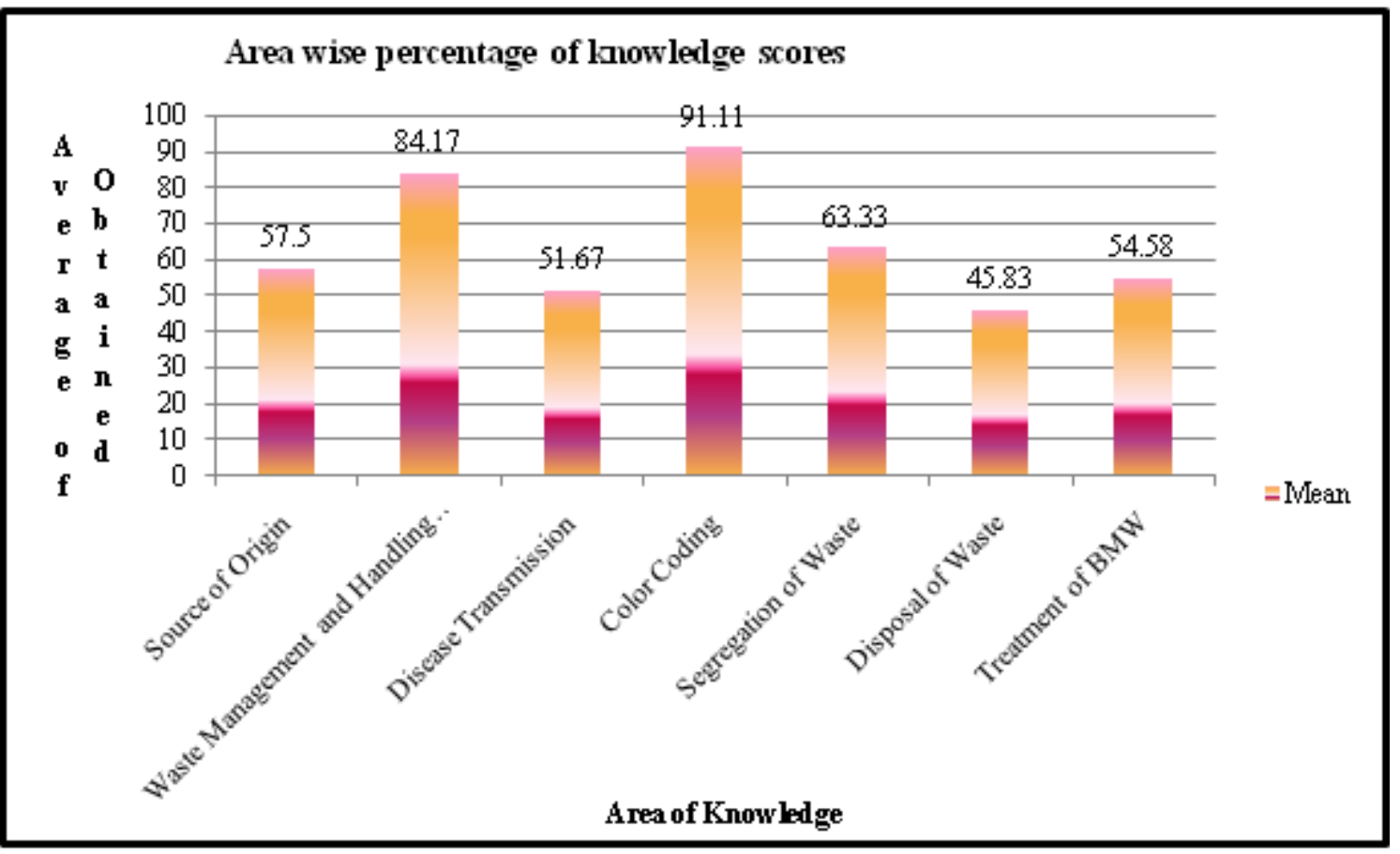

Area wise knowledge scores revealed that knowledge of respondents regarding color coding was $91.11 \%$, waste managent and handling rules $84.17 \%$, segregation of waste $63.3 \%$, source of origin 57.5\%, treatment of BMW 54.58\% and the lowest percentage of knowledge found for disposal of waste $45.83 \%$ which is the most sensitive aspect of BMW management. Hence it was necessary for the investigator to improve the knowledge by providing with information booklet.
The findings of the study was similar with study conducted by Chandra Boss and Jagdish (2013) which revealed that nurses used color bags indiscrimately and disposal of BMW were not adequately done which led to inappropriate management.

The findings revealed that the B.Sc nursing students had inadequate knowledge in the areas like methods of disposal of Bio medical waste, disease transmission and source of origin of BMW, so it is concluded that level of knowledge of 


\section{International Journal of Science and Research (IJSR) \\ ISSN (Online): 2319-7064 \\ Index Copernicus Value (2013): 6.14 | Impact Factor (2015): 6.391}

B.Sc nursing students can be enhanced by education and training programs.

Level of Knowledge regarding BMW management
The findings shows that high level of knowledge among respondents was $61.67 \%$, moderate level of knowledge among 33.33\% and low level of knowledge was 5\% among respondents regarding BMW management.

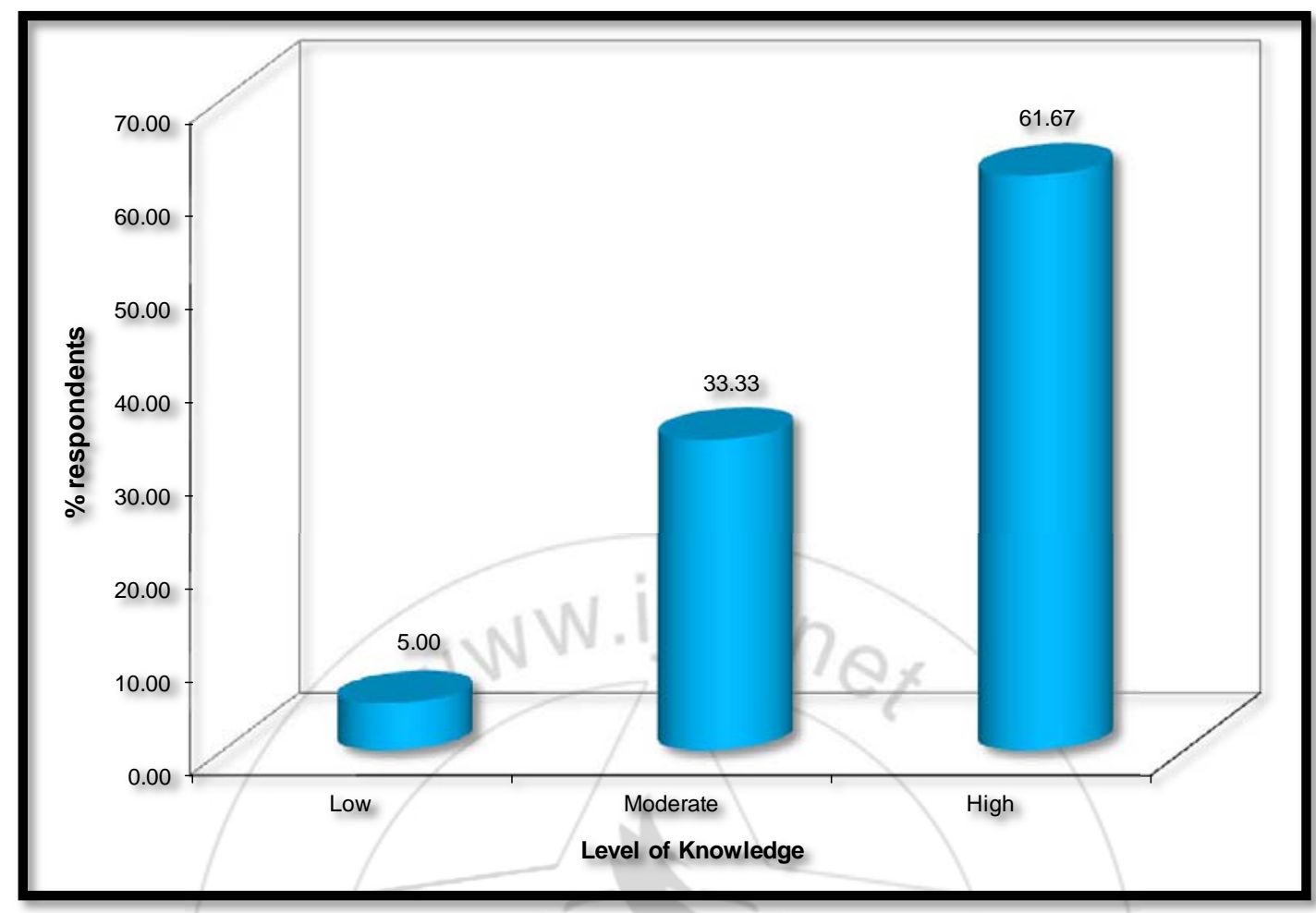

\section{Level of knowledge regarding BMW management}

The findings of the study was similar with study conducted by Chandra Boss and Jagdish which revealed that nurses used color bags indiscrimately and disposal of BMW were not adequately done which led in appropriate management.

\section{Association between knowledge scores and selected demographic variables}

Association between knowledge scores and selected demographic variables such as age in years $(\mathrm{f}=1.61)$, gender $(\mathrm{z}=-0.67)$, class $(\mathrm{f}=0.788)$ area of residence $(\mathrm{z}=-078)$, awareness regarding BMW management $(\mathrm{z}=1.43)$, source of information $(\mathrm{f}=0.62)$.

This indicates that there is no significant association between demographic variables and knowledge scores regarding biomedical waste management.

\section{Recommendations}

Based on the findings of the study the following recommendations are suggested:-

- A similar study can be conducted for large population of preservice and inservice nurses.

- Comparative study can be conducted for diploma \& degree nursing students.

- Co relational study can be conducted on knowledge attitude \& practice among nursing students on this topic.
- Experimental study can be conducted on knowledge attitude and practices of B.Sc nursing students of Bio medical waste management.

\section{References}

[1] The Gazette Of India, (2000). Biomedical waste (handling and management) rules 1998 amended number. 375.

[2] Kihore J, Joshi T.K. et al (2006) "Biomedical Management for nursing professional", Nursing Journal of India 2000 June; 91(6):129-36.

[3] Kermode M, Jolly .D. et al (2008) "Occupational exposure to blood and born virus infection among health care workers" American Journal of Infection Control Feb;33(1):34-41.

[4] Srivastava, J.N., (2004). Hospital Waste Management project at Command Hospital, Bangalore. National Seminar MJAFI, Volume 60, No. 4 (2004).

[5] Chandra, Bose and Jagdish, N, (2009). Study on Biomedical waste generation. Journal of environmental health, $80-84$.

[6] Park, K., (2008). Preventive and social medicine, 19th edition, 649.

[7] Rao, H.V.N., (1995). Disposal of hospital wastes and their impact on environment, 3rd international conference on waste management technologies, Nagpur. $839-842$.

[8] Gayatri, V, Patil and Pokrel, Kamla, (2004). Biomedical Solid Waste Management in an Indian Hospital, a case study. Vol.25, Issue - 6, 592 - 599. 


\section{International Journal of Science and Research (IJSR) \\ ISSN (Online): 2319-7064}

Index Copernicus Value (2013): 6.14 | Impact Factor (2015): 6.391

[9] Krishna, G., (2004). Health Care Workers - Victims of Occupational Hazards, IMC India -Online Article.

[10] Santoshi, Neeraj, (2009). Biomedical waste management lax in Jammu hospitals - Online Article, $82-89$.

[11] Joglekar, K.S., (2005). Hospital Waste Management, Ist edition, Vora Medical Publications, 78 - 81.

[12] Hemchandra and Sunil, Shishoo, (2007). Study on biomedical waste management of sharps - Online Article, 42 - 48.

[13] Verma, K., Lalit and Sinha, Neetu, (2008). Study on Biomedical Waste Management in nursing homes and smaller hospitals in Delhi, 50 -60.

[14] Rao, P, Hanumanta, (2008). Report on Hospital Waste Management - Awareness \& Practices; a study of three states in India, Waste management \& research, Vol. 26, No. 3, 297 - 303.

[15] Radha, K.V., Kalaivani, K., et. al., (2009). A case study on biomedical waste management in hospitals, Global journal of health sciences, Vol. 1, No. 1, 82 -88.

[16]Askarian, (2006). Evaluation of biomedical waste management, ISHWM, Vol. 5, Issue - 1, 1- 3.

[17] Yadavannar, Aditya S Berad (2007), "Biomedical waste management: A study of Knowledge, Attitude, Practices in a Tertiary Health Care Institution in Bijapur" Indian Journal of Community Medicine: 2010;35(1), 170-171.

[18] Pandit B, Mehta HK et al "Management of biomedical waste management: awareness \& practices in a district of Gujarat, Indian Journal of Public Health. 2005;49:245-7.

[19] Md. Asadullah, Kartik G.K. (2013), "A study on knowledge, attitude and practices regarding bio medical waste management" international journal of geology, 2013, Vol. 3 pp. 118-123.

[20] Mir Rafiq, Ahmad Javid et al. (2013), "Knowledge, attitude and practices about bio medical waste management" IOSR Journal of Nursing and Health Sciences", Vol. 1, issue 5, pp. 47-48.

[21] Rathod Dinesh et al. (2012), "Evaluation of awareness programme on practices of bio medical waste management", IJCRR, 4 (19), pp. 159-164. 